DOI: $10.15193 /$ zntj/2019/121/318

\title{
WACŁAW ADAMCZYK \\ THE ROLE OF ECO-INNOVATIONS IN DEVELOPING SUSTAINABLE PRODUCTS
}

\begin{abstract}
S u m m a ry
A characteristic feature that is directly or indirectly related to a quality of sustainable product originating from eco-innovation are the relationships with customers, which consist in meeting their needs and expectancies. However, those customer needs and expectancies are not always consistent with the concept of sustainable development. The customer is a very important link in performing the "customer to customer" quality management process for he is a source of information and a recipient of market offers. However, due to their potential and creativity, designers and constructors are those, who finally play a significant role in developing the quality of sustainable product.

The objective of the research study was analysis of the context of sustainable product in the light of the theory of quality management and sustainable development, competitive role of eco-innovations and consumer perception. Based on the reference literature analysis, a thesis has been formulated that the diffusion of eco-innovations is a stimulus to developing a sustainable product. Eco-innovations are perceived by manufacturers as a source of gaining a competitive advantage. On the basis of surveys of the manufacturers of food and electronic equipment, there were established the competitiveness determinants for product eco-innovations. Also, customer surveys were conducted to identify the most common sources of information about eco-innovations. It has been shown that descriptive characteristics of food products and the designation of energy classes for electronic products can be included into those sources.
\end{abstract}

Key words: eco-innovations, diffusion models, sustainable product, quality

\section{Introduction}

In global economic competition, innovation issues play an utmost role. In order to implement the concept of sustainable development and circular economy, it is insufficient to meet customer needs declared as the main objective of activities and a product quality attribute. The quality context can be identified in any fields of science. Economic and technology disciplines play a leading role. Being the subject matter of many

Prof. dr hab. W. Adamczyk, Katedra Technologii i Ekologii Wyrobów, Instytut Nauk o Jakości i Zarzqdzania Produktem, Uniwersytet Ekonomiczny w Krakowie, ul. Rakowicka 27, 31-510 Kraków.

Kontakt:waclaw.adamczyk@uek.krakow.pl 
science disciplines, the quality of sustainable objects has a complex and multidimensional nature.

The starting point for understanding the term "sustainable product" is the analysis of quality categories in the context of sustainable development guidelines. In the reference literature there are many definitions of quality; they represent a differentiated perspective on the quality - product-man relationships. Garvin [9] presented seven perspectives on those relationships including: transcendent (general), strategic, multidimensional, user-based, manufacturing-based, product-based and value-based.

There are a number of examples of analyses of those definitions in the scientific literature. The quality context can be identified in any field of science and practice, thus at high differentiation and plurality of test objects quality items have a multidimensional nature.

When analysing the context of quality definition both from the manufacturer's and the customer's point of view, it is easy to find the recurring designates:

- quality is the ability to satisfy needs,

- quality is a value,

- quality is a set of characteristics.

Combining those designates leads to the conclusion that, due to a set of characteristics quality is the ability to meet needs through deciding on its value. The definition featured in PN-EN ISO 9001:2015-10 [19] states that the quality of products and services provided by an organisation is determined by its ability to meet customer needs and by the intended or unintended effect on stakeholders. Although customer satisfaction, like preferences, is important in the business sense, it is not consistent even with respect to the product itself. Conducted under the competitive conditions, marketing research has an effect on developing the quality function in the whole life cycle of the product from designing to waste disposal. Meeting customer needs under increasing competition and overproduction leads to an increased resource consumption and wastage of raw materials and energy. Meeting customer needs declared as the main objective of activities and a product quality attribute is insufficient for implementing the concept of sustainable development and circular economy. Apart from depletion of non-renewable raw material resources, the manufacturing processes and product uses are the source of environmental losses and harmful emissions. Thus one may conclude that homo faber also means homo profusus.

\section{Sustainable product quality}

In the Genichi Taguchi theory of quality loss there is presented an original approach to quality that is, after modifying the object features, more compliant with the sustainable development guidelines. Generally positively perceived as a value in the Taguchi theory, the quality is connected with a quality loss of products: "quality as the 
loss a product causes to society" [22]. When considering the losses related to the use of the energy and raw material resources as well as the ecological consequences of manufacturing processes and product usage in the form of harmful emissions and waste, the Taguchi theory of quality loss is best suited for assumptions of sustainable development in the economic, ecological and social aspects. The loss costs are borne, to some extent, by consumers. According to Belz and Peattie [3, 4], the total cost born by the consumer includes:

- acquisition (price + purchase costs - manufacturing process and transportation losses),

- usage (energy use, maintenance, repairs),

- after use costs (waste management).

Each of those costs includes the costs resulting from the environmental losses.

An important issue is to reduce losses by minimising process variability, while considering that social losses relate not only to manufacturers and consumers but also to other social groups that do not benefit from quality management, but participate in losses by being exposed to harmful emissions and effects of resource depletion. Therefore it is necessary to include ecological properties in the product quality attributes.

While maintaining the principle of satisfying needs, it is possible to determine the condition with a minimal loss for each quality feature during the product development process. To achieve this assumption, Taguchi proposes the use of a loss function that enables to establish the actual state within accepted tolerances of deviance from optimal values [22].

This is the starting point for designing and creating control processes and for the attempts to determine and verify tolerance limits. This is especially complicated in the case, where it is necessary to take into account the state of environment and ecosystem reaction to changes. Assuming the initial state of environment as a background level, each change causes that its value is described by the loss function in the general form:

$$
\mathrm{L}(\mathrm{x})=\mathrm{K}(\mathrm{x}-\mathrm{m})^{2}
$$

where:

$\mathrm{L}-$ loss,

$\mathrm{K}$ - constant that refers to the loss type and tolerance limits,

$\mathrm{x}$ - state of the object,

$\mathrm{m}$ - target state of the object.

Due to the target value of quality, its attributes can be the maximum, minimum or nominal values and therefore it is important to choose an appropriate function form [2, $11,15]$. 
It is characteristic of sustainable products and its manufacturing processes, usage and after use disposal to achieve quality attributes that correspond to the target values specified by the sustainable development requirements while minimising variability.

\section{Sustainable product development}

Sustainable products feature an optimal environmental impact throughout their entire life cycle. Due to technological and scientific development, and changing consumer preferences, a continuous improvement is required of sustainable products to achieve goals defined in the triad of sustainable development.

To define a loss function in the context of sustainable problem development, it is necessary to consider that the manufacturing process variability is relatively small compared to changes in the conditions, under which the product should fulfil its function. This requires a comprehensive approach to designing and to environmental assessment of the life cycle; here the economic and social aspects should be included by applying a complex methodology chosen individually for the product specifics. The most commonly used methods comprise LCA and LCC as they represent a comprehensive approach to the environmental aspects and life cycle costs of the sustainable products. QFD (Quality Function Deployment) is used to transform the voice of customer into engineering characteristics, and the AHP method supports decision making processes. Those methods allow the structure of product quality attributes to be modelled and simulated in the context of the sustainable product system.

In general, the sustainable product development can be shown as follows:

1. Identifying technological and market realities and determining the level of ecoinnovations.

2. Assessing environmental impact of sustainable products with respect to reference products.

3. Modelling and simulations to optimise environmental impacts with other quality attributes.

4. Developing a product concept, while considering enterprise strategy and cost analysis.

5. Testing the test-version to verify the target quality attributes of sustainable products.

6. Technological and marketing development (ecological development).

7. Launching a sustainable product on the market.

8. Analysing the final product life cycle stages and user opinions.

Sustainable marketing plays an especially important role as it is targeted at the market research and at providing manufacturers and designers with necessary information [3]. This enhances a sustainable production. On the other hand addressing the appropriately prepared information to consumers enhances the sustainable and respon- 
sible consumption as does the provision of educational activities related to sustainable products to create the consumer ecological imperative. It is easy to notice that sustainable marketing promotes both the manufacturers and the consumers, while embracing social and economic relations. This requires special care of high ethical standards.

The implementation of sustainable development rules in overproduction and competitive conditions is based primarily on innovative activities.

\section{Eco-innovation characteristics}

In the twentieth and twenty first centuries the issue of innovation was present in many publications, mainly in the management and technical sciences and it was subject to a gradual evolution. Already in the 1930s Schumpeter [21] deemed innovations to be a driving force of economic growth, while considering innovations as a creative destruction arising from the introduction of a new raw material source, product, manufacturing method or organisational change, or opening a new market. A number of attempts to define innovations undertaken by Whitfield [24], Freeman [8], Drucker [7], Griffin [10], Kotler [14], Rogers [20] preceded the synthetic definition published by OECD [17] and based on the subject criteria [5]. Innovation was simply a new or significantly improved product, process as well as an organisational or marketing method [24].

The increasing importance of environmental issues and their linkages with the economic growth formed into a triad of ecological, economic and social problems is the foundation of sustainable development as a strategic goal of the EU. Within the framework of the Eco-Innovation Action Plan, UE stimulates the eco-innovation by supporting small and medium-sized enterprises in this field [23]. Innovations being a driving force of economic growth must be oriented towards reducing negative environmental impacts compared to those of alternative solutions. While achieving this goal, they become eco-innovations [13]. Thus, the eco-innovations comprise new products, manufacturing methods, resource use procedures, management and servicing methods that reduce the related environmental risks, e.g. resource consumption or harmful emissions throughout the entire life cycle of the product. It should be emphasized that the eco-innovations lead to double externality effects related to sustainable product development, technologies, organisational activities and environmental and social effects. The source of social effects are, in the first place, so called the add-on eco-innovations that include products and services enhancing the ecological awareness of consumers and creating the consumer ecological imperative. In turn, the integrated eco-innovations combine a few eco-innovations of common final effects into an environmentally friendly process and product. The alternative product eco-innovations result in highly reduced environmental impacts of products available on the market. In coincidence with the above mentioned eco-innovations, there are macro-organizational 
eco-innovations, i.e. innovative organisational structures promoting effective social life patterns, e.g. sustainable production and consumption. Moreover, the technologies referred to as general purpose eco-innovations play an important indirect role. Drucker highlights the significance of entrepreneurship in the implementation of innovative activities and the multiplication of their effects through innovation diffusion processes $[6,12]$.

Therefore, the sustainable product development is possible, among other things, by spreading innovations through diffusion processes. Their course is characterised by a model approach developed by Bass and Rogers [quoted after 16]. According to the Rogers' model, there are various categories of customers; some of them seek for novelties and they are the first to purchase innovative products, while other customers prefer proven products (Fig. 1).

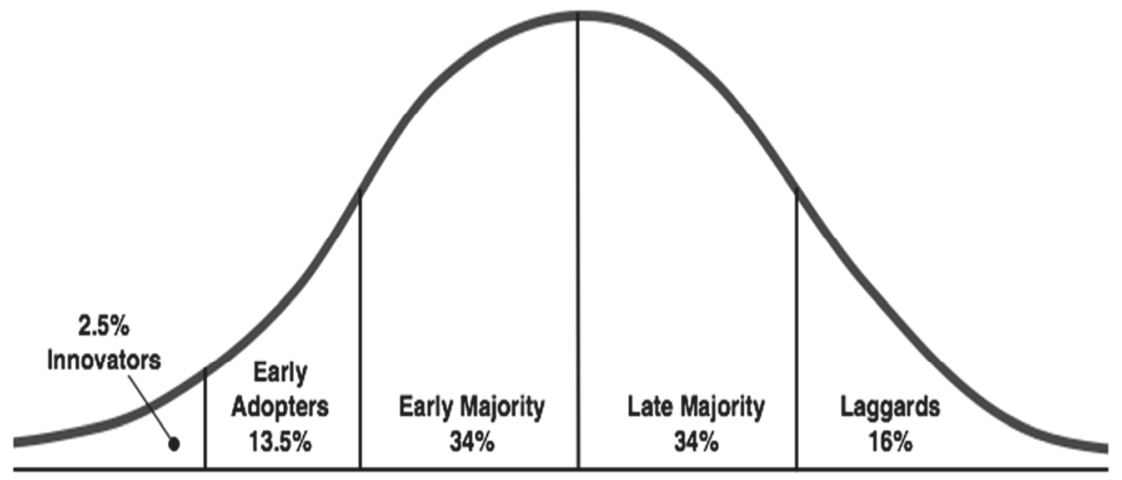

Explanatory notes / Objaśnienia:

Innovators / Innowatorzy; Early adopters / Wcześni naśladowcy; Early Majority / Wczesna większość; Late Majority / Późna większość; Laggards / Maruderzy.

Fig. 1. Categories of innovation adopters according to Rogers [25]

Rys. 1. Kategorie nabywców innowacji według Rogersa [25]

The Bass' innovation diffusion model describes an increase in the number of innovation adopters by the following equation [18]:

$$
\frac{d N(t)}{d t}=\left[p+q \frac{N(t)}{m}\right][m-N(t)]
$$

here:

$\mathrm{dN}(\mathrm{t}) / \mathrm{dt}$ - increase in the number of innovation adopters, $\mathrm{m}$ - total number of potential and current innovation adopters,

$\mathrm{p}$ - coefficient of innovation to indicate the effect of marketing activities on diffusion, 
$q$ - coefficient of imitation to indicate the effect of observation and replication of innovations by the users,

$[\mathrm{m}-\mathrm{N}(\mathrm{t})]-$ number of potential users based on the assumption that the innovation is fully adopted on the market.

The analytical solution of the Bass' model is a bell-shaped curve. Normally, after launching an innovative product on the market, the first group of purchasers inform other customer groups about the product qualities. The condition for diffusion of innovation, and hence the market success, is that q, the coefficient of imitation, has to be greater than $\mathrm{p}$, the coefficient of innovation. Also the estimation of the Bass' model parameters is practically applied to forecast sales [1].

\section{Perception of eco-innovation by customers and manufacturers}

The sustainable product development requires the research to be performed on the production and consumption and followed by the analysis and synthesis of results to develop a structure of quality attributes necessary in the eco-designing process. An important source of primary information that initiates the sustainable product development process is the perception of eco-innovations by customers and manufacturers. For the manufacturers, it is important to perceive eco-innovations as a source of competitive advantage. The producers should specify, which eco-innovations accompanying factors of competitiveness they prefer.

To evaluate the competitiveness impacting effect of eco-innovations, a survey was conducted among the managers of large and medium-sized industrial enterprises $(\mathrm{n}=86)$. The implemented eco-innovations were indicated as a competition determinant by 49 companies, i.e. by $56.9 \%$ of all the respondents. The remaining 37 enterprises indicated the following barriers to the eco-innovation implementation:

- cost and lack of financial means $(86.48 \%)$,

- lack of knowledge about the market reaction (81\%),

- lack of management engagement in innovative activities (70.27\%).

Next, there were surveyed the companies, which indicated the eco-innovations as a competition determinant $(\mathrm{n}=49)$. The respondents believed that the following key factors determined the competitiveness of enterprises under investigation:

- positive relations with customers $(74 \%)$,

- prices $(69.38 \%)$,

- product quality (61.22\%).

To determine the source of eco-innovation perception by customers, a survey was conducted on the intentionally selected customer group $(\mathrm{n}=136)$. The customers in commercial chains purchased industrial products (electrical and electronic equipment) and the basic food products. The respondents were city residents aged 25 to 45 , with secondary or tertiary education. 
The survey results indicated that the eco-innovation perception was declared by the purchasers of electrical and electronic equipment through:

- energy efficiency class $(84.5 \%)$,

- ecological labels (37.5\%),

- knowledge about the ecological properties of products (36.7\%),

- manufacturer's declarations $(29.4 \%)$.

The food purchasers declared that the eco-innovation was perceived through:

- product description (89.2\%),

- knowledge about the ecological properties of products (52.1\%),

- energy value $(48.3 \%)$,

- eco-labels $(21.4 \%)$.

In the case of the industrial products, special attention was paid to the energy efficiency class assigned to the product eco-innovation that also had an economic context related to lower operating costs.

In the case of the food products, it was easy to find that the product description was the most significant factor in perceiving the eco-innovations. A relatively high position of the knowledge about the food products resulted from the current trends in healthy nutrition and food. Also a greater significance was assigned to the knowledge about the properties of food products. This could be associated with the common knowledge about the traditional food products, which made a specific comeback in a new marketing form of the ecological innovations.

As for the industrial products, to a lesser extent the respondents pointed out the ecological properties of the product as a source of knowledge about the eco-innovation; in their opinions the reason thereof was the dynamic development and the need to have specialized knowledge of how to consciously perceive changes in the products.

The energy value of the food products was linked with the eco-innovations by $48.3 \%$ of the respondents. This factor might be the maximum or minimum value depending on the function the food product fulfilled in the purchaser's dietary pattern. The results showed that the eco-labels on the food products enjoyed little popularity $(21.4 \%)$ compared to the typical labelling of the industrial products.

\section{Conclusions}

1. The results obtained indicate that the implementation of eco-innovations, the basis of sustainable product development, is of utmost significance for improving the competitiveness of the enterprise through positive relations with customers as are the product price and quality.

2. In the opinions of the companies surveyed the lack of implementation of ecoinnovations results from the lack of financial means, lack of knowledge about sustainable products and the lack of engagement in innovative activities. 
3. The principal conclusion resulting from the research carried out is that for the customers the source of knowledge about eco-innovations depends primarily on the kind of product. However the results indicate that the lack of financial means is the main barrier to the eco-innovation implementation. A passive approach to ecoinnovations emphasizes this barrier.

\section{Acknowledgements}

Praca została sfinansowana ze środków przyznanych przez MNiSzW na utrzymanie potencjału badawczego Wydziału Towaroznawstwa i Zarzadzania Produktem Uniwersytetu Ekonomicznego w Krakowie.

\section{References}

[1] Bartłomowicz T.: Prognozowanie sprzedaży z wykorzystaniem modelu dyfuzji oraz programu R. Ekonometria, 2012, 4 (38), 210-220.

[2] Belavendram N.: Quality by Design. Prentice Hall, London 1995.

[3] Belz F.M., Peattie K.: Sustainability marketing - An innovative conception of marketing. Marketing Rev. St. Gallen, 2010, 27, 8-15.

[4] Belz F.M., Peattie K.: Sustainability marketing: A Global Perspective. Wiley and Sons, Chichester 2009, pp. 149-243.

[5] Carrillo-Hermosilla J., del Rio P., Könnölä T.: Diversity of eco-innovations: Reflections from selected case studies. J. Cleaner Prod., 2010, 18 (10-11), 1073-1083.

[6] Drucker P.: Innowacja i przedsiębiorczość. Praktyka i zasady. PWE, Warszawa 1992, s. 271.

[7] Drucker P.: Management: Tasks, Responsibilities, Practices. HarperBusiness, New York City 1993.

[8] Freeman Ch.: The Economics of Industrial Innovation. Pinter, London 1982, p. 57.

[9] Garvin D.A.: What does "product quality" really mean? MIT Sloan Manag. Rev., 1984, 1 (26).

[10] Griffin R.: Podstawy zarządzania organizacjami. Wyd. Nauk. PWN, Warszawa 1996.

[11] Hamrol A., Mantura W.: Zarządzanie jakością. Teoria i praktyka. Wyd. Nauk. PWN, Warszawa 2004, ss. 246-247.

[12] Karakaya E., Hidalgo A., Nuur C.: Diffusion of eco-innovations: A review. Renewable Sustainable Energy Rev., 2014, 33, 392-399.

[13] Kemp R., Pearson P.: Final Report Measuring Eco-Innovation Project About Measuring EcoInnovation. Maastricht Economic and Social Research Institute on Innovation and Technology, Maastricht 2007, pp. 7-8.

[14] Kotler P.: Marketing Management. Pearson Custom Publishing, Boston 2000, p. 355.

[15] Lofthouse T.: The Taguchi loss function. Work Study, 1999, 48 (6), 218-223.

[16] Meade N., Islam T.: Modelling and forecasting the diffusion of innovation - A 25-year review. Int. J. Forecasting, 2006, 22 (3), 519-545.

[17] OECD/Eurostat: Oslo Manual: Guidelines for Collecting and Interpreting Innovation Data. $3^{\text {rd }}$ ed. OECD Publishing, Paris 2005.

[18] Philippas D.T.: A mathematical Model for Financial Innovation: Empirical Evidence from Financial Markets. University of Patras, Patras 2011, pp. 33-34.

[19] PN-EN ISO 9001:2015-10. Systemy zarządzania jakością. Wymagania.

[20] Rogers E.M.: Difusion of Innovations. $5^{\text {th }}$ ed. Free Press, New York City 2003, p. 12. 
[21] Schumpeter J.A.: Business Cycles: A Theoretical, Historical and Statistical Analysis of the Capitalist Process. McGraw-Hill Book Company, New York City 1939.

[22] Taguchi G.: The development of quality engineering. ASI Journal, 1988, 1, 1-4.

[23] Triguero A., Moreno-Mondéjar L., Davia M.A.: Drivers of different types of eco-innovation in European SMEs. Ecological Economics, 2013, 92, 25-33.

[24] Whitfield P.R.: Innowacje w przemyśle. PWE, Warszawa 1979, s. 26.

[25] Value Based Management [on line]. Dostęp w Internecie [10.03.2019]: www.valuebasedmanagement.net

\title{
ROLA EKOINNOWACJI W ROZWOJU PRODUKTÓW ZRÓWNOWAŻONYCH
}

\author{
Streszczenie
}

Cechą charakterystyczną występującą bezpośrednio lub pośrednio w związku z jakością produktu zrównoważonego powstałego w wyniku ekoinnowacji są relacje z klientem, polegające na spełnieniu jego oczekiwań i potrzeb. Nie zawsze jednak oczekiwania i potrzeby konsumentów są zgodne z ideą zrównoważonego rozwoju. Klient jest bardzo ważnym ogniwem w realizowaniu procesu zarządzania jakością „od klienta do klienta", będąc źródłem informacji i adresatem oferty rynkowej. Z uwagi jednak na potencjał producentów oraz kreatywność projektantów i konstruktorów, to właśnie im ostatecznie należy przypisać znaczącą rolę w kreowaniu jakości produktu zrównoważonego.

Celem pracy była analiza kontekstu produktu zrównoważonego z uwzględnieniem teorii zarządzania jakością i zrównoważonego rozwoju, a także konkurencyjnej roli ekoinnowacji i ich postrzegania przez konsumentów. Na podstawie analizy literatury sformułowano tezę, że bodźcem do rozwoju produktu zrównoważonego jest dyfuzja ekoinnowacji. Ekoinnowacje postrzegane są przez producentów jako źródło osiągania przewagi konkurencyjnej. Na podstawie badań ankietowych wśród producentów żywności i producentów sprzętu elektronicznego określono determinanty konkurencyjności ekoinnowacji produktowych. Przeprowadzono również badania konsumenckie celem identyfikacji najbardziej popularnych źródeł informacji o ekoinnowacjach. Wykazano, że do tych źródeł można zakwalifikować charakterystyki opisowe produktów żywnościowych oraz oznaczenia klas energetycznych produktów elektronicznych.

Słowa kluczowe: ekoinnowacje, modele dyfuzji, zrównoważony produkt, jakość 